Arq. Bras. Med. Vet. Zootec., v.56, n.6, p.764-772, 2004

\title{
Qualidade de silagens de sorgo com aditivos
}

\author{
[Quality of sorghum silages with additives] \\ F.A.P. Vieira ${ }^{1}$, I. Borges $^{2}$, C.A.V. Stehling ${ }^{3}$, L.C. Gonçalves ${ }^{2}$, \\ S.G. Coelho ${ }^{2}$, M.I.C. Ferreira ${ }^{3}$, J.A.S. Rodrigues ${ }^{4}$ \\ ${ }^{1}$ Doutoranda em Ciência Animal - EVUFMG \\ ${ }^{2}$ Escola de Veterinária da UFMG \\ ${ }^{3}$ Médica Veterinária \\ ${ }^{4}$ Embrapa Milho e Sorgo
}

\begin{abstract}
RESUMO
Um delineamento inteiramente ao acaso, com três repetições, foi utilizado para avaliar os efeitos da adição de $0,5 \%$ de uréia, de $0,5 \%$ de carbonato de cálcio $\left(\mathrm{CaCO}_{3}\right)$, de $0,5 \%$ de uréia mais $0,5 \%$ de $\mathrm{CaCO} 3$ e de inoculante bacteriano sobre o $\mathrm{pH}$, teores de matéria seca (MS), proteína bruta (PB), fibra em detergente neutro (FDN), fibra em detergente ácido (FDA), hemicelulose, celulose, lignina, carboidratos solúveis, ácido lático e ácido acético sobre a digestibilidade in vitro da matéria seca (DIVMS) de silagens de quatro híbridos de sorgo (BR700, BR701, BR601 e AG2002). Os híbridos ensilados sem a adição de aditivos constituíram o grupocontrole. De cada genótipo foram coletadas três amostras do material original (MOR). Foram utilizados 60 silos de PVC com $10 \mathrm{~cm}$ de diâmetro interno e $50 \mathrm{~cm}$ de comprimento, sendo três por tratamento. A abertura dos silos ocorreu depois de 56 dias de fermentação. As silagens contendo $\mathrm{CaCO}_{3}$ e inoculante bacteriano apresentaram, em geral, características muito semelhantes às do controle. A adição de uréia e de uréia mais $\mathrm{CaCO}_{3}$ às silagens resultou em aumento $(\mathrm{P}<0,05)$ nos teores de $\mathrm{PB}$. A adição conjunta de uréia e $\mathrm{CaCO}_{3}$ não propiciou aumento $(\mathrm{P}<0,05)$ superior ao obtido nas silagens contendo apenas uréia. Uréia pura, como aditivo, pode ser recomendada na ensilagem dos híbridos BR700, BR601 e AG2002.
\end{abstract}

Palavras-chave: uréia, carbonato de cálcio, inoculante bacteriano, padrões de fermentação

\begin{abstract}
A completely randomized design with three replicates was used to evaluate the addition effects of $0.5 \%$ urea, $0.5 \%$ calcium carbonate, $0.5 \%$ urea plus $0.5 \%$ calcium carbonate, and bacteria culture (according to producer recommendations) on quality of four hybrids sorghum silages (BR700, BR701, BR601 e AG2002). All hybrids ensiled with no additives were used as the control group. The $\mathrm{pH}$ and the contents of dry matter (DM), crude protein $(C P)$, neutral detergent fiber $(N D F)$, acid detergent fiber (ADF), hemicellulose, cellulose, lignin, soluble carbohydrates, lactic and acetic acids, and the in vitro dry matter digestibility (IVDMD) values were determined. Three samples of each original material (MOR) were collected and analyzed. Sixty "PVC" experimental silos with $10 \mathrm{~cm}$ of internal diameter and $50 \mathrm{~cm}$ of length, three by treatment, were used. The silos were open after 56 days of fermentation. The results of silages containing calcium carbonate or bacteria culture were, in general, similar to the control group (without additives). The addition of urea and urea plus calcium carbonate to silages improved their $C P$ contents $(P<0.05)$. The addition of urea plus calcium carbonate did not improve the CP contents of silages in relation to the addition of only urea. The addition of urea can be recommended for silages of BR700, BR601 and AG2002 hybrids.
\end{abstract}

Keywords: urea, bacteria culture, calcium carbonate

*Endereço para correspondência (mailing address)

Rua Cesário Alvim, 118-Bairro Padre Eustáquio - 30720-270 - Belo Horizonte, MG

E-mail: flaviavieira26@hotmail.com

Recebido para publicação em 11 de dezembro de 2003

Recebido para publicação, após modificações, em 10 de agosto de 2004 


\section{INTRODUÇÃO}

No Brasil, devido às condições climáticas, a disponibilidade de forragens é irregular ao longo do ano, com períodos alternados de excesso e escassez de pastagens. Para que não ocorra reflexo negativo da estacionalidade na produção do rebanho, é necessário que o excesso de forragens produzido no período chuvoso seja conservado para ser utilizado no período seco, garantindo aos animais boa qualidade de alimentação volumosa ao longo de todo o ano. A ensilagem, que consiste na fermentação anaeróbica de plantas forrageiras, constitui-se em boa opção de conservação de alimentos volumosos (McDonald et al., 1991)

Segundo Zago e Pozar (1991), a principal cultura para produção de silagem no Brasil é a do milho. O sorgo (Sorghum bicolor, L. Moench) ocupa lugar secundário, sendo responsável por $10-12 \%$ da área total cultivada para esse fim. O sorgo é uma cultura muito versátil, prestando-se à produção de grãos, de feno, de silagem e ao pastejo direto. Apresenta tolerância à seca e às limitações de nutrientes no solo, sendo boa opção em regiões impróprias para o plantio do milho.

Além das limitações nutricionais, o processo de ensilagem apresenta riscos que podem levar a perdas de nutrientes decorrentes de fermentações indesejáveis. Sabe-se que uma grande variedade de aditivos é comercializada com o propósito de solucionar as limitações à obtenção de silagens de boa qualidade nas condições tropicais (Henderson, 1993).

A Tab. 1 apresenta uma compilação de características qualitativas utilizadas por diversos autores para avaliação de silagens.

Tabela 1. Classificação qualitativa de silagens segundo diversos critérios

\begin{tabular}{|c|c|c|c|c|c|}
\hline Parâmetro & Muito Boa & Boa & Satisfatória & Ruim & Fonte \\
\hline \multirow{3}{*}{ MS (\%) } & $30-35$ & & & & PAIVA (1976) \\
\hline & & $>25$ & & & McDONALD et al. (1991) \\
\hline & & $20-29$ & & & MEESKE et al. (1993) \\
\hline \multirow{2}{*}{$\mathrm{pH}$} & $<3,8$ & $3,8-4,2$ & $4,2-4,6$ & $>4,6$ & PAIVA (1976) \\
\hline & & $3,8-4,2$ & & & VILELA (1998) \\
\hline \multirow{2}{*}{ Ácido láctico (\%MS) } & $4-6$ & & & & ROTH e UNDERSANDER (1995) \\
\hline & $>5$ & $5-3$ & $3-2$ & $<2$ & RODRIGUEZ et al. (1999) \\
\hline \multirow{2}{*}{ Ácido acético (\%MS) } & $<2$ & & & & ROTH e UNDERSANDER (1995) \\
\hline & $<2,5$ & $>2,5$ & $>2,5$ & $>2,5$ & RODRIGUEZ et al. (1999) \\
\hline Ácido propiônico (\%MS) & $<0,5$ & & & & ROTH e UNDERSANDER (1995) \\
\hline Äcido butírico (\%MS) & $<0,1$ & & & & ROTH e UNDERSANDER (1995) \\
\hline \multirow{3}{*}{ Etanol (\%MS) } & $<0,1$ & $0,1-0,2$ & $0,2-0,4$ & $>0,4$ & PAIVA (1976) \\
\hline & $<0,5$ & & & & ROTH e UNDERSANDER (1995) \\
\hline & & $<1$ & & & McDONALD et al. (1991) \\
\hline \multirow{3}{*}{$\mathrm{N}$-amoniacal (\% do $\mathrm{N}$ total) } & $0-10$ & $10-15$ & $15-20$ & $>20$ & $\operatorname{AFRC~(1987)~}$ \\
\hline & $<5$ & & & & ROTH e UNDERSANDER (1995) \\
\hline & & $<12$ & & & MOLINA et al. (2002a; 2000b) \\
\hline NIDA $(\%$ do $\mathrm{N}$ total $)$ & $<12$ & & & & ROTH e UNDERSANDER (1995) \\
\hline $\begin{array}{l}\text { Carboidratos solúveis (\% na MS do } \\
\text { material original) }\end{array}$ & $>2,5$ & & & & PETTERSON e LINDGREN (1989) \\
\hline FDN (\% da MS) & $<41$ & & & & McDONALD et al. (1991) \\
\hline FDA ( $\%$ da MS) & $<22$ & & & & McDONALD et al. (1991) \\
\hline $\operatorname{DIVMS}^{5}(\%)$ & $>65$ & $65-55$ & $55-40$ & $<40$ & PAIVA (1976) \\
\hline Leveduras (UFC/g silagem) & $<100.000$ & & & & ROTH e UNDERSANDER (1995) \\
\hline Fungos (UFC/g silagem) & $<100.000$ & & & & ROTH e UNDERSANDER (1995) \\
\hline Aeróbios totais (UFC/g silagem) & $<100.000$ & & & & ROTH e UNDERSANDER (1995) \\
\hline $\begin{array}{l}\text { Bactérias ácido-lácticas (UFC/g de } \\
\text { silagem) }\end{array}$ & $>10^{8}$ & & & & MUCK (1988) \\
\hline
\end{tabular}


Os objetivos deste trabalho foram avaliar as características bromatológicas, as concentrações de carboidratos solúveis e de ácidos orgânicos e a digestibilidade in vitro da matéria seca de silagens de quatro híbridos de sorgo puras (sem aditivos), adicionadas de uréia, carbonato de cálcio, uréia mais carbonato de cálcio ou de inoculante bacteriano comercial.

\section{MATERIAL E MÉTODOS}

Foram utilizados quatro cultivares de sorgo, sendo dois forrageiros (BR601 e AG2002) e dois de duplo propósito (BR700 e BR701), plantados e colhidos nas dependências da Embrapa Milho e Sorgo, no município de Sete Lagoas, Minas Gerais.

A colheita ocorreu quando os grãos apresentavam-se no estádio leitoso-pastoso, sendo o corte manual, rente ao solo. O material foi picado em picadeira estacionária.

Os aditivos foram adicionados, em porcentagem do material verde, no momento da ensilagem, nas seguintes proporções: $0,5 \%$ de uréia; $0,5 \%$ de $\mathrm{CaCO}_{3} ; 0,5 \%$ de uréia mais $0,5 \%$ de $\mathrm{CaCO}_{3}$; e dois litros de solução (1g de produto em cada litro de água) por tonelada de forragem de inoculante bacteriano ${ }^{1}$. A adição foi feita no material espalhado sobre lona plástica, procedendo-se mistura vigorosa.

Os silos utilizados foram de PVC com $10 \mathrm{~cm}$ de diâmetro interno e $50 \mathrm{~cm}$ de comprimento, fechados com tampas dotadas de válvulas tipo Bunsen e lacrados com fita crepe.

Utilizaram-se três repetições por tratamento incluindo o controle (silagens sem aditivos), totalizando 60 silos.

Os silos foram abertos após 56 dias de fermentação. Para as determinações do $\mathrm{pH}$, nitrogênio amoniacal como porcentagem do nitrogênio total $\left(\mathrm{N}-\mathrm{NH}_{3} / \mathrm{NT}\right)$, ácidos orgânicos, matéria seca (MS), proteína bruta (PB), digestibilidade in vitro da matéria seca (DIVMS), fibra em detergente neutro (FDN), fibra em detergente ácido (FDA), hemicelulose, celulose, lignina e carboidratos solúveis foram

${ }^{1}$ Silobac ${ }^{\circ}$ - Chr. Hansen Ind. Com. Ltda - Valinhos, SP adotadas as metodologias de Tilley e Terry (1963), Bailey (1967), Association... (1980) e Van Soest (1994).

O delineamento experimental foi o inteiramente ao acaso com três repetições por tratamento. Utilizou-se o teste SNK para a comparação entre médias dos híbridos, dentro de cada tratamento, e entre médias dos tratamentos, dentro de cada híbrido $(\mathrm{P}<0,05)$. As correlações entre variáveis foram determinadas pelo método de Pearson. $\mathrm{O}$ pacote estatístico utilizado foi o SAEG 7.0 (Sistema..., 1998).

Para as variáveis MS, PB, FDN, FDA, hemicelulose, celulose, lignina, DIVMS e carboidratos solúveis, avaliadas nos dois tipos de material (MOR e silagem), adotou-se esquema fatorial $6 \times \times 4 \times 3$ (tratamentos $\times$ híbridos $\times$ repetições). Para as variáveis $\mathrm{pH}, \mathrm{N}-\mathrm{NH}_{3} / \mathrm{NT}$ e ácidos orgânicos, avaliadas apenas no material ensilado, utilizou-se esquema fatorial $5 \times 4 \times 3$ (tratamentos $\times$ híbridos $\times$ repetições).

Nas variáveis em que não houve interação híbrido versus tratamento, as comparações foram feitas somente entre as médias gerais. Quando a interação foi significativa, efetuou-se o desdobramento para comparação das médias.

\section{RESULTADOS E DISCUSSÃO}

Não houve efeito $(\mathrm{P}<0,05)$ dos aditivos sobre os conteúdos de MS dos MOR e das silagens (Tab. 2). Este fato é explicado tendo em vista que nenhum dos aditivos utilizados caracteriza-se por alterar os teores de MS. Este resultado foi semelhante aos obtidos por Higginbotham et al. (1998) e Meeske e Basson (1998). O teor de MS do MOR do híbrido BR700 não pôde ser determinado por falhas no momento da amostragem.

Os mais baixos teores de MS $(\mathrm{P}<0,05)$ foram obtidos nas silagens do híbrido AG2002, com exceção daquela com inoculante bacteriano, na qual não houve diferença $(\mathrm{P}>0,05)$ entre este híbrido e o BR601.

A adição exclusiva de uréia e $\mathrm{CaCO}_{3}$ elevou o $\mathrm{pH}$ das silagens em relação à silagem-controle nos híbridos BR700 e BR701 (Tab. 3). 
Tabela 2. Teor de matéria seca (\%) no material original e nas silagens de quatro híbridos de sorgo sem e com aditivos

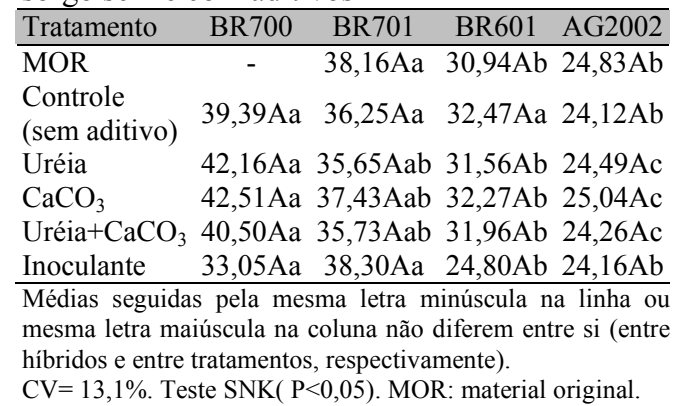

Tabela 3. Valor de $\mathrm{pH}$ do suco das silagens de quatro híbridos de sorgo sem e com aditivos

\begin{tabular}{|c|c|c|c|c|}
\hline Tratamento & BR700 & BR701 & BR601 & AG2002 \\
\hline $\begin{array}{l}\text { Controle } \\
\text { (sem aditivo) }\end{array}$ & 3,87Dab & $3,92 \mathrm{Da}$ & $3,74 \mathrm{Bb}$ & $3,75 \mathrm{Bb}$ \\
\hline Uréia & $4,48 \mathrm{Bb}$ & $5,29 \mathrm{Ba}$ & $3,87 \mathrm{Bc}$ & $3,86 \mathrm{Bc}$ \\
\hline $\mathrm{CaCO}_{3}$ & $4,20 \mathrm{Cb}$ & $4,43 \mathrm{Ca}$ & $3,89 \mathrm{Bc}$ & $3,84 \mathrm{Bc}$ \\
\hline Uréia $+\mathrm{CaCO}_{3}$ & $4,72 \mathrm{Ab}$ & $5,81 \mathrm{Aa}$ & $4,30 \mathrm{Ac}$ & $4,05 \mathrm{Ad}$ \\
\hline Inoculante & $3,79 \mathrm{Db}$ & $3,98 \mathrm{Da}$ & $3,87 \mathrm{Bab}$ & $3,72 \mathrm{Bb}$ \\
\hline
\end{tabular}

A maior elevação do $\mathrm{pH}$ foi observada quando da adição de uréia mais $\mathrm{CaCO}_{3}$ nas silagens de todos os híbridos estudados $(\mathrm{P}<0,05)$. Este efeito provavelmente deveu-se à ação tamponante conjunta dos íons amônio e Ca. O poder tampão impediu a acidificação da massa ensilada mesmo na presença de grande quantidade de ácido láctico, pois como será mostrado posteriormente, as silagens contendo uréia e $\mathrm{CaCO}_{3}$ apresentaram maior teor desse ácido do que as silagenscontrole e, ainda assim, os maiores valores de $\mathrm{pH}$.

A adição de inoculante bacteriano não resultou em efeito $(\mathrm{P}>0,05)$ sobre os valores de $\mathrm{pH}$ das silagens, provavelmente devido ao grande número de bactérias ácido-lácticas (BAL) presentes no MOR.

Observou-se correlação negativa $(\mathrm{r}=-0,40$; $\mathrm{P}<0,01)$ entre $\mathrm{pH}$ e MS nas silagens. No geral, os materiais com maiores teores de umidade, BR601 e AG2002 nessa ordem, apresentaram os menores valores de $\mathrm{pH}$, indicando que a acidificação é inibida pelos baixos teores de umidade e pela alta pressão osmótica da massa ensilada.

Segundo Vilela (1998), pH entre 3,8 e 4,2 é o desejável para silagem considerada bem conservada. No entanto, o pH, isoladamente, não pode ser considerado como critério seguro para avaliação das silagens, pois seu efeito inibidor sobre as bactérias e enzimas das plantas depende da velocidade do declínio da concentração iônica e do grau de umidade do meio. Utilizando as classificações propostas na Tab. 1, com relação aos valores de $\mathrm{pH}$, as silagens sem aditivos e aquelas contendo $\mathrm{CaCO}_{3}$ ou inoculante bacteriano podem ser consideradas muito boas ou boas. Em silagens contendo uréia mais $\mathrm{CaCO}_{3}$, o pH não é um bom critério de caracterização da qualidade, devido ao efeito tamponante dos sais de amônio e do $\mathrm{Ca}$.

A adição de uréia e uréia mais $\mathrm{CaCO}_{3}$ elevou o teor de $\mathrm{N}_{-} \mathrm{NH}_{3} / \mathrm{NT}$ nas silagens de todos os híbridos, em relação à silagem-controle (Tab. 4). Esse aumento provavelmente é atribuído ao teor de nitrogênio não-protéico (NNP) desses aditivos, promovendo alcalinização da massa ensilada e condições adequadas para ação das enzimas proteolíticas das plantas e dos microrganismos. Além disso, os maiores valores de $\mathrm{pH}$ foram obtidos nas silagens adicionadas de uréia mais $\mathrm{CaCO}_{3}$ (Tab. 3).

Tabela 4. Teor de nitrogênio amoniacal como porcentagem do nitrogênio total do suco das silagens de quatro híbridos de sorgo sem e com aditivos

\begin{tabular}{lcccc}
\hline Tratamento & BR700 & BR701 & BR601 & AG2002 \\
\hline Controle & $0,26 \mathrm{Bb}$ & $3,18 \mathrm{Ca}$ & $4,62 \mathrm{Ca}$ & $4,94 \mathrm{Ca}$ \\
Uréia & $5,95 \mathrm{Ac}$ & $41,50 \mathrm{Ba}$ & $15,70 \mathrm{Bb}$ & $16,22 \mathrm{Bb}$ \\
$\mathrm{CaCO}_{3}$ & $0,39 \mathrm{Bb}$ & $3,62 \mathrm{Ca}$ & $4,95 \mathrm{Ca}$ & $5,45 \mathrm{Ca}$ \\
Uréia $^{+} \mathrm{CaCO}_{3}$ & $5,58 \mathrm{Ad}$ & $43,44 \mathrm{Aa}$ & $29,68 \mathrm{Ab}$ & $19,11 \mathrm{Ac}$ \\
Inoculante & $0,38 \mathrm{Bb}$ & $3,29 \mathrm{Ca}$ & $4,94 \mathrm{Ca}$ & $5,12 \mathrm{Ca}$
\end{tabular}

Médias seguidas pela mesma letra minúscula na linha ou mesma letra maiúscula na coluna não diferem entre si (entre híbridos e entre tratamentos, respectivamente).

$\mathrm{CV}=10,4 \%$. Teste SNK $(\mathrm{P}<0,05)$.

A utilização exclusiva de $\mathrm{CaCO}_{3}$ ou inoculante bacteriano não alterou os teores de $\mathrm{N}-\mathrm{NH}_{3} / \mathrm{NT}$ das silagens em relação ao do controle, provavelmente porque os valores de $\mathrm{pH}$ obtidos (Tab. 3) foram suficientemente baixos para prevenir a proteólise excessiva. 
Segundo Henderson (1993), os principais fatores que determinam a extensão da degradação protéica no material ensilado são: o conteúdo de $\mathrm{MS}$, a presença de oxigênio, o $\mathrm{pH}$ e a temperatura.

Observou-se correlação positiva entre os teores de $\mathrm{N}_{-} \mathrm{NH}_{3} / \mathrm{NT}$ e os valores de $\mathrm{pH} \quad(\mathrm{r}=0,39$; $\mathrm{P}<0,01)$. Esse efeito indica que a acidificação do meio promoveu desnaturação das enzimas proteolíticas, causando redução no valor nutritivo da silagem pela conversão de proteínas em NNP. A maioria dessas enzimas é ativa somente em $\mathrm{pH}$ acima de cinco. Além disso, em $\mathrm{pH}$ próximo a quatro ocorre inibição das bactérias do gênero Clostridium, que também são responsáveis por proteólise.

Não houve correlação $(\mathrm{P}>0,05)$ entre os teores de $\mathrm{N}-\mathrm{NH}_{3} / \mathrm{NT}$ e de $\mathrm{MS}$, indicando que os níveis de umidade foram adequados para prevenir a proteólise excessiva.

Segundo as classificações propostas na Tab. 1, em relação aos teores de $\mathrm{N}-\mathrm{NH}_{3} / \mathrm{NT}$, as silagens sem aditivo e aquelas contendo $\mathrm{CaCO}_{3}$ ou inoculante bacteriano podem ser consideradas muito boas. Assim como o $\mathrm{pH}$, a porcentagem de $\mathrm{N}-\mathrm{NH}_{3} / \mathrm{NT}$, isoladamente, não é uma característica confiável na avaliação qualitativa de silagens contendo uréia, pois sendo um subproduto dela, os níveis de amônia estarão aumentados nessas silagens, não indicando necessariamente fermentação inadequada.

$\mathrm{A}$ adição de uréia ou de uréia mais $\mathrm{CaCO}_{3}$ às silagens aumentou substancialmente $(\mathrm{P}<0,05)$ o teor de PB (Tab. 5). A uréia é fonte de NNP, o que justifica essa observação. $\mathrm{O}$ aumento médio foi de $42 \%$ em relação à silagem-controle. Não houve diferença $(\mathrm{P}>0,05)$ entre os valores de $\mathrm{PB}$ observados nas silagens adicionadas de uréia mais $\mathrm{CaCO}_{3}$ e aquelas contendo apenas uréia. Estes resultados assemelham-se aos obtidos por Gonçalves et al. (1998).

Não houve diferença significativa entre os valores de $\mathrm{PB}$ das silagens com adição de $\mathrm{CaCO}_{3}$ e as silagens-controle, indicando que o cálcio, presente nesse aditivo, não propiciou aumentos na síntese de proteína microbiana e, portanto, não foi um nutriente limitante.
Tabela 5. Teor de proteína bruta (\%) no material original e nas silagens de quatro híbridos de sorgo sem e com aditivos

\begin{tabular}{lcccc}
\hline Tratamento & BR700 & BR701 & BR601 & AG2002 \\
\hline MOR & - & $7,69 \mathrm{Ba}$ & $5,91 \mathrm{Bb}$ & $6,88 \mathrm{Ca}$ \\
Controle & $7,59 \mathrm{Bab}$ & $7,82 \mathrm{Ba}$ & $6,62 \mathrm{Bb}$ & $7,45 \mathrm{Cab}$ \\
Uréia & $9,43 \mathrm{Ab}$ & $9,91 \mathrm{Ab}$ & $10,12 \mathrm{Ab}$ & $12,46 \mathrm{Aa}$ \\
$\mathrm{CaCO}_{3}$ & $7,42 \mathrm{Bab}$ & $7,88 \mathrm{Ba}$ & $6,51 \mathrm{Bb}$ & $7,42 \mathrm{Cab}$ \\
$\mathrm{Uré}^{2}+\mathrm{CaCO}_{3}$ & $9,25 \mathrm{Ab}$ & $9,35 \mathrm{Ab}$ & $10,18 \mathrm{Aab}$ & $10,56 \mathrm{Ba}$ \\
Inoculante & $8,74 \mathrm{Aa}$ & $7,6 \mathrm{Bb}$ & $6,56 \mathrm{Bc}$ & $7,27 \mathrm{Cbc}$ \\
\hline \multicolumn{2}{l}{ Médias seguidas pela mesma letra minúscula na linha ou } \\
mesma letra maiúscula na coluna não diferem entre si (entre \\
híbridos e entre tratamentos, respectivamente). \\
$\mathrm{CV}=6,3 \%$. Teste SNK $(\mathrm{P}<0,05)$. MOR: material original.
\end{tabular}

A adição de inoculante bacteriano elevou $(\mathrm{P}<0,05)$ a concentração de $\mathrm{PB}$ das silagens em relação à do controle apenas quando se utilizou o híbrido BR700, indicando que a inoculação corrigiu uma provável deficiência na concentração de BAL nesse material.

No geral, as silagens-controle apresentaram teor de FDN inferior àquele do MOR, indicando que os microrganismos presentes na massa ensilada degradaram parte dessa fração fibrosa (Tab. 6).

Tabela 6. Teor de fibra em detergente neutro (\%) no material original e nas silagens de quatro híbridos de sorgo sem e com aditivos

\begin{tabular}{lcccc}
\hline Tratamento & BR700 & BR701 & BR601 & AG2002 \\
\hline MOR & - & $64,67 \mathrm{Aa}$ & $60,27 \mathrm{Ab}$ & $53,53 \mathrm{Ac}$ \\
Controle & $55,10 \mathrm{Aa}$ & $55,03 \mathrm{Ca}$ & $47,87 \mathrm{Db}$ & $50,27 \mathrm{ABb}$ \\
$\mathrm{Uréia}$ & $56,63 \mathrm{Ab}$ & $60,70 \mathrm{ABa}$ & $54,33 \mathrm{Bbc}$ & $51,93 \mathrm{Ac}$ \\
$\mathrm{CaCO}_{3}$ & $58,60 \mathrm{Aa}$ & $57,30 \mathrm{BCa}$ & $49,10 \mathrm{CDb}$ & $46,10 \mathrm{Bb}$ \\
$\mathrm{Uré}^{2}+\mathrm{CaCO}_{3}$ & $56,73 \mathrm{Ab}$ & $61,33 \mathrm{ABa}$ & $54,23 \mathrm{Bbc}$ & $50,70 \mathrm{ABc}$ \\
Inoculante & $54,80 \mathrm{Ab}$ & $58,67 \mathrm{BCa}$ & $52,77 \mathrm{BCbc}$ & $50,03 \mathrm{ABc}$ \\
\hline \multicolumn{4}{l}{ Médias seguidas pela mesma letra minúscula na linha ou } \\
mesma letra maiúscula na coluna não diferem entre si (entre \\
híbridos e entre tratamentos, respectivamente). \\
$\mathrm{CV}=4,1 \%$. Teste SNK $\mathrm{P}<0,05$. MOR: material original.
\end{tabular}

As silagens dos híbridos BR701 e BR601 com uréia ou uréia mais $\mathrm{CaCO}_{3}$ apresentaram teores de FDN superiores $(\mathrm{P}<0,05)$ aos do controle. Entretanto, não houve efeito $(\mathrm{P}>0,05)$ da adição isolada de $\mathrm{CaCO}_{3}$ sobre o referido teor, indicando que a uréia pode ter afetado negativamente o desenvolvimento das bactérias fibrolíticas.

Não houve alteração no teor de FDA $(\mathrm{P}>0,05)$ em razão da adição de uréia e inoculante bacteriano nas silagens dos híbridos BR700, BR701 e AG2002 (Tab. 7). Os demais aditivos 
não promoveram alteração no teor de FDA $(\mathrm{P}>0,05)$ na silagem de nenhum dos híbridos.

Tabela 7. Teor de fibra em detergente ácido (\%) no material original e nas silagens de quatro híbridos de sorgo sem e com aditivos

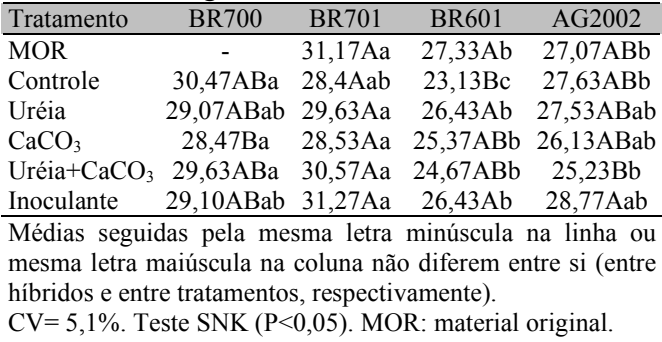

Houve redução $(\mathrm{P}<0,05)$ no teor de hemicelulose na silagem dos híbridos BR701, BR601 e AG2002 em relação ao MOR. As silagens com aditivos, à exceção daquelas com uréia e uréia mais $\mathrm{CaCO}_{3}$ do híbrido BR701, e $\mathrm{CaCO}_{3}$ do híbrido BR700 (Tab. 8), apresentaram teor de hemicelulose igual ou inferior ao do controle. De acordo com Hunt et al. (1993), as hemiceluloses parecem ser o principal substrato para a fermentação, após a utilização dos carboidratos solúveis, podendo haver degradação de até 50\% do total presente no MOR.

Tabela 8. Teor de hemicelulose (\%) no material original e nas silagens de quatro híbridos de sorgo sem e com aditivos

\begin{tabular}{lcccc}
\hline Tratamento & $\mathrm{BR} 700$ & $\mathrm{BR} 701$ & $\mathrm{BR} 601$ & $\mathrm{AG} 2002$ \\
\hline MOR & - & $33,50 \mathrm{Aa}$ & $32,93 \mathrm{Aa}$ & $26,47 \mathrm{Ab}$ \\
Controle & $24,63 \mathrm{Bab}$ & $26,63 \mathrm{Ca}$ & $24,73 \mathrm{Dab}$ & $22,63 \mathrm{BCb}$ \\
Uréia & $27,57 \mathrm{Bb}$ & $31,07 \mathrm{ABa}$ & $27,90 \mathrm{BCb}$ & $24,40 \mathrm{ABc}$ \\
$\mathrm{CaCO}_{3}$ & $30,13 \mathrm{Aa}$ & $28,77 \mathrm{BCa}$ & $23,73 \mathrm{Db}$ & $19,97 \mathrm{Cc}$ \\
$\mathrm{Uré}^{-}+\mathrm{CaCO}_{3}$ & $27,10 \mathrm{Bbc}$ & $30,77 \mathrm{ABa}$ & $29,57 \mathrm{Bab}$ & $25,47 \mathrm{ABc}$ \\
Inoculante & $25,70 \mathrm{Ba}$ & $27,40 \mathrm{Ca}$ & $26,33 \mathrm{CDa}$ & $21,27 \mathrm{Cb}$ \\
\hline \multicolumn{4}{l}{ Médias seguidas pela mesma letra minúscula na linha ou } \\
mesma letra maiúscula na coluna não diferem entre si (entre \\
híbridos e entre tratamentos, respectivamente). \\
$\mathrm{CV}=5,7 \%$. Teste $\mathrm{SNK}(\mathrm{P}<0,05)$. MOR: material original.
\end{tabular}

Houve redução $(\mathrm{P}<0,05)$ no teor de celulose na silagem dos híbridos BR701 e BR601 em relação ao MOR.

A silagem dos híbridos BR701 e BR601 adicionada de uréia pura ou com $\mathrm{CaCO}_{3}$, e a inoculada, apresentaram teor de celulose superior $(\mathrm{P}<0,05)$ ao do controle (Tab. 9).
Tabela 9. Teor de celulose (\%) no material original e nas silagens de quatro híbridos de sorgo sem e com aditivos

\begin{tabular}{lcccc}
\hline Tratamento & BR700 & BR701 & BR601 & AG2002 \\
\hline MOR & - & $26,13 \mathrm{Aa}$ & $23,97 \mathrm{Aab}$ & $22,50 \mathrm{Ab}$ \\
Controle & $25,13 \mathrm{ABa}$ & $22,03 \mathrm{Bb}$ & $19,53 \mathrm{Bc}$ & $23,73 \mathrm{Aab}$ \\
Uréia & $23,93 \mathrm{ABa}$ & $24,60 \mathrm{Aa}$ & $23,30 \mathrm{Aa}$ & $23,87 \mathrm{Aa}$ \\
$\mathrm{CaCO}_{3}$ & $23,17 \mathrm{Ba}$ & $23,97 \mathrm{ABa}$ & $22,10 \mathrm{Aa}$ & $22,47 \mathrm{Aa}$ \\
$\mathrm{Uré}^{2}+\mathrm{CaCO}_{3}$ & $25,00 \mathrm{ABa}$ & $25,13 \mathrm{Aa}$ & $21,77 \mathrm{Ab}$ & $21,50 \mathrm{Ab}$ \\
Inoculante & $23,40 \mathrm{ABa}$ & $25,80 \mathrm{Aa}$ & $23,33 \mathrm{Aa}$ & $24,20 \mathrm{Aa}$ \\
\hline Médias seguidas pela mesma letra minúscula na linha ou \\
mesma letra maiúscula na coluna não diferem entre si (entre \\
híbridos e entre tratamentos, respectivamente). \\
$\mathrm{CV}=5,5 \%$. Teste $\mathrm{SNK}(\mathrm{P}<0,05)$. MOR: material original.
\end{tabular}

A adição exclusiva de $\mathrm{CaCO}_{3}$ não alterou $(\mathrm{P}<0,05)$ o teor de celulose da silagem dos híbridos BR700, BR701 e AG2002 em relação ao do controle.

A ausência de resposta à adição, conjunta ou isolada, de uréia e $\mathrm{CaCO}_{3}$ sobre as frações fibrosas da parede celular pode indicar que os nutrientes fornecidos por esses aditivos não propiciaram crescimento na população de microrganismos e, portanto, não foram limitantes. Nos casos em que houve aumento das frações fibrosas, pode-se suspeitar que os aditivos propiciaram desequilíbrios no meio, prejudicando a ação das bactérias fibrolíticas.

A resposta à inoculação parece indicar que as BAL presentes no inoculante apresentaram maior afinidade por substratos mais solúveis, em detrimento da parede celular.

Não houve diferença nos teores de lignina entre os tratamentos (Tab. 10). Por ser um composto de pouca, ou nenhuma digestibilidade, essa resposta é bastante coerente.

Tabela 10. Teor de lignina (\%) no material original e nas silagens de quatro híbridos de sorgo sem e com aditivos

\begin{tabular}{lccccc}
\hline Tratamento & BR700 & BR701 & BR601 & AG2002 & Média \\
\hline MOR & - & 5,03 & 3,37 & 4,57 & $4,67 \mathrm{~A}$ \\
Controle & 5,33 & 6,37 & 3,60 & 3,90 & $4,80 \mathrm{~A}$ \\
Uréia & 5,13 & 5,03 & 3,13 & 3,67 & $4,24 \mathrm{~A}$ \\
$\mathrm{CaCO}_{3}$ & 5,30 & 4,57 & 3,27 & 3,67 & $4,20 \mathrm{~A}$ \\
$\mathrm{Uréia}^{+} \mathrm{CaCO}_{3}$ & 4,63 & 5,43 & 2,90 & 3,73 & $4,18 \mathrm{~A}$ \\
Inoculante & 5,70 & 5,47 & 3,10 & 4,57 & $4,71 \mathrm{~A}$ \\
\hline Médias seguidas pela mesma letra minúscula na linha ou \\
mesma letra maiúscula na coluna não diferem entre si (entre \\
híbridos e entre tratamentos, respectivamente). \\
$\mathrm{CV}=12,0 \%$. Teste SNK $(\mathrm{P}<0,05)$ MOR: material original.
\end{tabular}


$\mathrm{A}$ adição de uréia, de $\mathrm{CaCO}_{3}$, ou de inoculante não propiciou aumento $(\mathrm{P}>0,05)$ nos valores de DIVMS das silagens, exceto aquelas do BR700 (Tab. 11).

Tabela 11. Digestibilidade in vitro da matéria seca (\%) do material original e das silagens de quatro híbridos de sorgo sem e com aditivos

\begin{tabular}{lcccc} 
Tratamento & BR700 & BR701 & BR601 & AG2002 \\
\hline MOR & - & $59,88 \mathrm{Ab}$ & $63,17 \mathrm{ABa}$ & $58,91 \mathrm{Bb}$ \\
Controle & $55,86 \mathrm{Bb}$ & $57,12 \mathrm{Ab}$ & $61,12 \mathrm{ABa}$ & $57,52 \mathrm{Bb}$ \\
Uréia & $62,23 \mathrm{Aa}$ & $58,36 \mathrm{Ab}$ & $60,41 \mathrm{Bab}$ & $58,80 \mathrm{Bb}$ \\
$\mathrm{CaCO}_{3}$ & $61,52 \mathrm{Aa}$ & $59,29 \mathrm{Aa}$ & $54,91 \mathrm{Cb}$ & $61,21 \mathrm{ABa}$ \\
$\mathrm{Uré}^{2}+\mathrm{CaCO}_{3}$ & $61,52 \mathrm{Aa}$ & $56,38 \mathrm{Ab}$ & $64,24 \mathrm{Aa}$ & $62,70 \mathrm{Aa}$ \\
Inoculante & $61,70 \mathrm{Aa}$ & $56,97 \mathrm{Ab}$ & $59,93 \mathrm{Bab}$ & $58,27 \mathrm{Bb}$ \\
\hline \multicolumn{4}{l}{ Médias seguidas pela mesma letra minúscula na linha ou } \\
mesma letra maiúscula na coluna não diferem entre si (entre \\
híbridos e entre tratamentos, respectivamente). \\
$\mathrm{CV}=2,9 \%$. Teste SNK $(\mathrm{P}<0,05)$. MOR: material original.
\end{tabular}

A adição conjunta de uréia e $\mathrm{CaCO}_{3}$ propiciou aumento nos valores de DIVMS, em relação ao controle, das silagens dos híbridos BR700 e AG2002. Gonçalves et al. (1998) obtiveram maior DIVMS em silagens contendo esses aditivos.

De acordo com a classificação proposta por Paiva (1976) (Tab. 1), todas as silagens avaliadas são consideradas de boa qualidade, em relação aos valores de DIVMS.

Os maiores teores de carboidratos solúveis foram obtidos no MOR (Tab. 12), não sendo observada diferença significativa entre os tratamentos $(\mathrm{P}>0,05)$. Os carboidratos são $\mathrm{o}$ principal substrato para a fermentação no material ensilado, sendo quase totalmente consumidos durante o processo, o que explica esse efeito.

Tabela 12. Teor de carboidratos solúveis (\%) no material original e nas silagens de quatro híbridos de sorgo sem e com aditivos

\begin{tabular}{lcccc}
\hline Tratamento & BR700 & BR701 & BR601 & AG2002 \\
\hline MOR & - & $2,16 \mathrm{Ad}$ & $6,76 \mathrm{Ab}$ & $8,75 \mathrm{Aa}$ \\
Controle & $0,12 \mathrm{Ba}$ & $0,12 \mathrm{Ba}$ & $0,22 \mathrm{Ba}$ & $0,29 \mathrm{Ba}$ \\
Uréia & $0,08 \mathrm{Ba}$ & $0,09 \mathrm{Ba}$ & $0,22 \mathrm{Ba}$ & $0,34 \mathrm{Ba}$ \\
$\mathrm{CaCO}_{3}$ & $0,08 \mathrm{Ba}$ & $0,10 \mathrm{Ba}$ & $0,16 \mathrm{Ba}$ & $0,31 \mathrm{Ba}$ \\
$\mathrm{Uré}+\mathrm{CaCO}_{3}$ & $0,09 \mathrm{Ba}$ & $0,09 \mathrm{Ba}$ & $0,13 \mathrm{Ba}$ & $0,20 \mathrm{Ba}$ \\
Inoculante & $0,14 \mathrm{Ba}$ & $0,17 \mathrm{Ba}$ & $0,17 \mathrm{Ba}$ & $0,36 \mathrm{Ba}$ \\
\hline
\end{tabular}

Médias seguidas pela mesma letra minúscula na linha ou mesma letra maiúscula na coluna não diferem entre si (entre híbridos e entre tratamentos, respectivamente).

$\mathrm{CV}=12,7 \%$. Teste $\mathrm{SNK}(\mathrm{P}<0,05)$. MOR: material original.
Dentre os híbridos, o maior teor de carboidratos solúveis foi observado no AG2002, seguido, nesta ordem, pelo BR601 e BR701. Esta observação pode ser explicada em função do caráter sacarino, rico em carboidratos solúveis, do colmo dos híbridos AG2002 e BR601.

Os teores de carboidratos solúveis correlacionaram-se negativamente com aqueles de MS ( $\mathrm{r}=-0,26 ; \mathrm{P}<0,01)$ no MOR e nas silagens $(\mathrm{r}=-0,70 ; \mathrm{P}<0,01)$, FDN $(\mathrm{r}=-0,68 ; \mathrm{P}<0,01)$, FDA $(\mathrm{r}=-0,31 ; \quad \mathrm{P}<0,01), \quad$ hemicelulose $\quad(\mathrm{r}=-0,72$; $\mathrm{P}<0,01)$ e lignina $(\mathrm{r}=-0,41 ; \quad \mathrm{P}<0,01)$. Esses efeitos se justificam em função do aumento proporcional das frações fibrosas, com o aumento no teor de MS, e concomitante redução no conteúdo celular.

De acordo com a classificação proposta na Tab. 1 , todas as silagens, exceto aquelas do híbrido BR701, podem ser consideradas como de muito boa qualidade, pois apresentaram teores de carboidratos solúveis, no MOR, superiores a $2,5 \%$.

As silagens avaliadas apresentaram valores traço ou zero de ácido propiônico e butírico. Portanto, somente são apresentados os teores dos ácidos acético e láctico.

A Tab. 13 apresenta os teores de ácido acético das silagens sem e com aditivos. Não houve interação significativa entre híbridos e tratamentos

Tabela 13. Teor de ácido acético (\%) das silagens de quatro híbridos de sorgo sem e com aditivos

\begin{tabular}{lccccc}
\hline Tratamento & BR700 & BR701 & BR601 & AG2002 & Média \\
\hline Controle & 1,21 & 1,73 & 1,52 & 2,42 & $1,72 \mathrm{~B}$ \\
Uréia & 2,44 & 1,38 & 1,77 & 2,59 & $2,05 \mathrm{~B}$ \\
$\mathrm{CaCO}_{3}$ & 2,21 & 1,94 & 2,20 & 3,44 & $2,45 \mathrm{AB}$ \\
${\text { Uréia }+\mathrm{CaCO}_{3}}$ & 3,21 & 1,48 & 4,32 & 3,37 & $3,09 \mathrm{~A}$ \\
Inoculante & 1,21 & 1,77 & 2,19 & 2,93 & $2,02 \mathrm{~B}$ \\
\hline
\end{tabular}

Médias seguidas pela mesma letra minúscula na linha ou mesma letra maiúscula na coluna não diferem entre si (entre híbridos e entre tratamentos, respectivamente). $\mathrm{CV}=41,1 \%$. Teste SNK $(\mathrm{P}<0,05)$.

$\mathrm{O}$ tratamento com uréia mais $\mathrm{CaCO}_{3}$ foi o único que propiciou aumento $(\mathrm{P}<0,05)$ no teor de ácido acético em relação ao do controle. Este efeito provavelmente deveu-se à ação tamponante conjunta dos íons $\mathrm{Ca}$ e amônia aumentando a 
produção deste ácido. Scheffer de Rojas (1976) também observou maiores teores de ácido acético nas silagens de milho contendo $0,5 \%$ de uréia mais $0,5 \%$ de $\mathrm{CaCO}_{3}$, em relação àquelas sem aditivo.

Os teores de ácido acético apresentaram correlação positiva com o $\mathrm{pH}(\mathrm{r}=0,40 ; \mathrm{P}<0,01)$. Esta observação indica que o ácido acético não contribuiu na acidificação do material ensilado, talvez por estar presente em concentrações muito baixas.

Houve correlação negativa entre os teores de ácido acético e FDN ( $\mathrm{r}=-0,22 ; \mathrm{P}<0,05)$, e FDA $(\mathrm{r}=-0,28 ; \mathrm{P}<0,05)$ indicando que estes substratos foram utilizados para a fermentação acética. Observou-se correlação negativa entre ácido acético e MS ( $\mathrm{r}=0,73 ; \mathrm{P}<0,01)$, indicando que a baixa umidade e a pressão osmótica têm efeito inibidor sobre a fermentação.

A Tab. 14 apresenta os teores de ácido láctico das silagens sem e com aditivos. Não houve interação significativa entre híbridos e tratamentos.

Tabela 14. Teor de ácido láctico (\%) das silagens de quatro híbridos de sorgo sem e com aditivos

\begin{tabular}{lccccc}
\hline Tratamento & BR700 & BR701 & BR601 & AG2002 & Média \\
\hline Controle & 4,62 & 5,00 & 6,90 & 8,54 & $6,26 \mathrm{~B}$ \\
Uréia & 7,47 & 3,96 & 6,90 & 9,62 & $6,99 \mathrm{~B}$ \\
$\mathrm{CaCO}_{3}$ & 6,13 & 7,55 & 9,76 & 13,38 & $9,21 \mathrm{AB}$ \\
Uréia+CaCO $_{3}$ & 11,94 & 3,31 & 18,90 & 15,12 & $12,32 \mathrm{~A}$ \\
Inoculante & 4,58 & 6,64 & 5,47 & 7,65 & $6,08 \mathrm{~B}$
\end{tabular}

Médias seguidas pela mesma letra minúscula na linha ou mesma letra maiúscula na coluna não diferem entre si (entre híbridos e entre tratamentos, respectivamente).

$\mathrm{CV}=48,6 \%$. Teste $\mathrm{SNK} \mathrm{P}<0,05$.

$\mathrm{O}$ tratamento com uréia mais $\mathrm{CaCO}_{3}$ foi o único que propiciou aumento no teor de ácido láctico da silagem, em relação ao do controle. Provavelmente, ocorreu um somatório dos efeitos tamponantes dos sais de amônio e cálcio, uma vez que a adição isolada dos aditivos não resultou em estímulo à produção desse ácido. A ausência de resposta à inoculação pode ser devida a um alto número de BAL presente na cultura antes da ensilagem.

Observou-se correlação negativa entre o teor de ácido láctico e $\mathrm{pH}(\mathrm{r}=-0,47 ; \mathrm{P}<0,01)$, indicando que o ácido láctico é o principal responsável pela acidificação do material ensilado, em função do baixo Pka. Os teores de ácido láctico correlacionaram-se negativamente com as concentrações de MS $(\mathrm{r}=-0,75 ; \mathrm{P}<0,01)$, confirmando o efeito inibitório da umidade sobre a fermentação. Houve correlação negativa entre os teores de ácido láctico e $\mathrm{FDN}(\mathrm{r}=-0,29$; $\mathrm{P}<0,05)$, FDA $(\mathrm{r}=-0,37 ; \mathrm{P}<0,01)$ e celulose $(\mathrm{r}=$ $0,22 ; \mathrm{P}<0,05)$, indicando que esses substratos são utilizados na fermentação láctica.

De modo geral, todas as silagens avaliadas neste trabalho podem ser consideradas muito boas, em relação aos teores de ácido láctico, de acordo com as classificações propostas na Tab. 1 .

\section{CONCLUSÕES}

As silagens contendo $\mathrm{CaCO}_{3}$ e inoculante bacteriano como aditivos apresentaram, no geral, características muito semelhantes às do controle, não justificando, dessa forma, sua utilização em nenhum dos híbridos avaliados. A utilização de $0,5 \%$ de uréia pode ser recomendada nas silagens dos híbridos BR700, BR601 e AG2002.

\section{REFERÊNCIAS BIBLIOGRÁFICAS}

AFRC. Technical Commitee on Responses to Nutrients. Report n.2. Characterization of feedstuffs. Nutr. Abstr. Rev., Ser. B, v.57, p.713736, 1987.

ASSOCIATION Official Analytical Chemists. Official methods of analysis. 13.ed. Washington: AOAC, 1980.1015p.

BAILEY, R.W. Quantitative studies of ruminant digestion. II. Loss of ingested plant carbohydrates from the reticulo rumen. New Zeal. J. Agric. Res., v.10, p.15-32, 1967.

BORGES, A.L.C.C.; GONÇALVES, L.C.; NOGUEIRA, F.S. et al. Silagem de sorgo de porte baixo com diferentes teores de tanino e de umidade no colmo. II- Alterações nos carboidratos durante a fermentação. Arq. Bras. Med. Vet. Zootec., v.51, p.491-497, 1999.

GONÇALVES, L.C.; BORGES, A.L.C.C.; RODRIGUEZ, N.M. et al. Valor nutritivo de silagens de milho puras, ou adicionadas de uréia pura ou com carbonato de cálcio, e do rolão de milho. I- Consumo e digestibilidade aparente da 
matéria seca e da proteína bruta e balanço do nitrogênio. Arq. Bras. Med. Vet. Zootec., v.50, p.309-315, 1998.

HENDERSON, N. Silage additives. Anim. Feed Sci. Technol., v.45, p.35-56, 1993.

HIGGINBOTHAM, G.E.; MUELLER, S.C.; BOLSEN, K.K. et al. Effects of inoculants containing propionic acid bacteria on fermentation and aerobic stability of corn silage. J. Dairy Sci., v.81, p.2185-2192, 1998.

HUNT, C.W.; KEZAR, W.; HINMAN, D.D. et al. Effects of hybrid and ensiling with and without a microbial inoculant on the nutritional characteristics of whole-plant corn. J. Anim. Sci., v.71, p.38-43, 1993.

McDONALD, P.; HENDERSON, A.R.; HERON, S.J.E. The biochemistry of silage. 2.ed. Marlow: Chalcombe Publications, 1991. 340p.

MEESKE, R.; ASHBELL, G.; WEINBERG, Z.G. Ensiling forage sorghum at two stages of maturity with the addition of lactic acid bacterial inoculants. Anim. Feed Sci. Technol., v.43, p.165-175, 1993.

MEESKE, R.; BASSON, H.M. The effect of a lactic acid bacterial inoculant on maize silage. Anim. Feed Sci. Technol., v.70, p.239-247, 1998.

MOLINA, L.R.; GONÇALVES, L.C.; RODRIGUEZ, N.M. et al. Digestibilidade in situ das frações fibrosas de seis genótipos de sorgo (Sorghum bicolor (L) Moench) em diferentes estádios de maturação. Arq. Bras. Med. Vet. Zootec., v.54, p.169-179, 2002a.

MOLINA, L.R.; GONÇALVES, L.C.; RODRIGUEZ, N.M. et al. Qualidade das silagens de seis genótipos de sorgo (Sorghum bicolor (L) Moench) em diferentes estádios de maturação. Arq. Bras. Med. Vet. Zootec., v.54, p.159-168, 2002b.

MUCK, R.E. Factors influencing silage quality and their implications for management. J. Dairy Sci., v.71, p.2992-3002, 1988.

PAIVA, J.A.J. Qualidade das silagens da região metalúrgica de Minas Gerais. 1976. 85f.
Dissertação (Mestrado em Zootecnia) - Escola de Veterinária, Universidade Federal de Minas Gerais, Belo Horizonte.

PETTERSON, K.L.; LINDEREN, S. The influence of the carbohydrate fraction and additives on silage quality. Grass For. Sci., v.45, p.223-233, 1989.

RODRIGUEZ, N.M.; GONÇALVES, L.C.; NOGUEIRA, F.A.S. et al. Silagem de sorgo de porte baixo com diferentes teores de tanino e de umidade no colma. I- $\mathrm{pH}$ e teores de matéria seca e de ácidos graxos durante a fermentação. Arq. Bras. Med. Vet. Zootec., v.51, p.485-490, 1999.

ROTH, G.; UNDERSANDER, D. Silage additives. In: CORN SILAGE PRODUCTION MANAGEMENT AND FEEDING. Madison: Madison American Society of Agronomy, 1995. P.27-29.

SCHEFFER DE ROJAS, S.A. Efeito de aditivos $e$ do momento de vedação na qualidade da silagem de milho em condições de laboratório. 1976. 83f. Dissertação (Mestrado em Zootecnia) - Escola de Veterinária, Universidade Federal de Minas Gerais, Belo Horizonte.

SISTEMA de análises estatísticas e genéticas SAEG. Versão 7.0. Viçosa: UFV, 1998.

TILLEY, J.M.A.; TERRY, R.A. A two stage technique for the in vitro digestion of forage crops. J. Brit. Grass. Soc., v.18, p.104-111, 1963.

VAN SOEST, P.J. Nutritional ecology of the ruminant. 2.ed. Ithaca: Cornell University, 1994. $476 \mathrm{p}$.

VILELA, D. Aditivos para silagem de plantas de clima tropical. In: REUNIÃO ANUAL DA SOCIEDADE BRASILEIRA DE ZOOTECNIA, 35, 1998, Botucatu, SP. Anais...BOTUCATU:SBZ, 1998. P.73-108

ZAGO, C.P.; POZAR, G. Época de corte de sorgo (Sorghum bicolor L. MOENCH) e sua influência sobre a porcentagem de matéria seca e de panícula. In: REUNIÃO ANUAL DA SOCIEDADE BRASILEIRA DE ZOOTECNIA, 28., 1991. João Pessoa. Anais... JOÃO PESSOA:SBZ, 1991. P.61. 